\title{
Inhibition of the dimorphic transition of Candida albicans by the ornithine decarboxylase inhibitor 1,4-diaminobutanone: alterations in the glycoprotein composition of the cell wall
}

\author{
Jose P. Martinez, ${ }^{1}$ Jose L. Lopez-Ribot, ${ }^{1}$ Maria L. Gil, ${ }^{1}$ Rafael SentandreU ${ }^{1}$ and \\ JOSE RUIZ-HERRERA ${ }^{2 *}$ \\ ${ }^{1}$ Departament de Microbiologia, Facultat de Farmacia, Universitat de Valencia, 46010, Valencia, Spain \\ ${ }^{2}$ Centro de Investigacion y Estudios Avanzados, IPN, and Instituto de Investigacion en Biologia Experimental, Facultad \\ de Quimica, Universidad de Guanajuato, Apartado Postal 187, Gto. 36000, Mexico
}

(Received 15 February 1990; revised 26 June 1990; accepted 4 July 1990)

\begin{abstract}
Hyphal development in Candida albicans was selectively blocked by the ornithine decarboxylase competitive inhibitor 1,4-diaminobutanone (DAB). Inhibition of hyphal development required DAB during both yeast inoculum growth and subsequent incubation at $37^{\circ} \mathrm{C}$ to induce mycelial growth. This effect was not due to general growth inhibition since DAB did not inhibit yeast growth, and reduced protein synthesis by $30 \%$ at most. Moreover, protein synthesis was unaffected by DAB when cells were pre-grown in drug-containing media. Since DAB inhibited dimorphic transition at $37^{\circ} \mathrm{C}$, morphology- and temperature-dependent protein synthesis could be distinguished. DAB stimulated the synthesis of several yeast wall-proteins, irrespective of morphology or growth temperature, and two at $37^{\circ} \mathrm{C}$ only, but it inhibited the synthesis of a single mycelial-specific glycoprotein species.
\end{abstract}

\section{Introduction}

Candida albicans is an important opportunistic pathogenic fungus, and is also polymorphic, although two forms (the budding yeast and septate mycelium) are the most frequently found (for reviews see Odds, 1988; Soll, 1985). These two morphologies occur in infected tissues, and no clear differences in pathogenicity can be ascribed to them (Odds, 1988). However, it appears that the hyphal form is involved in the early stages of invasion, penetrating into the tissues (Anderson \& Odds, 1985; Cawson \& Rajasingham, 1972; Farrel et al., 1983; Rajasingham \& Cawson, 1982), adhering to epithelia (Anderson \& Odds, 1985; Kimura \& Pearsall, 1980; Sandin \& Rogers, 1982; Sobel \& Obedeanu, 1983), and avoiding phagocytosis (Smith, 1985). The mechanisms involved in the yeast-mycelial transition of $C$. albicans are therefore important for both theoretical and practical reasons.

Abbreviations: DAB, 1,4-diaminobutanone; ODC, ornithine decarboxylase; Con $\mathrm{A}$, concanavalin $\mathrm{A}$; mAb, monoclonal antibody.
Polyamines are required for cellular growth and differentiation in many organisms (Heby, 1981; Tabor \& Tabor, 1984), and for spore germination in several fungi (Kim, 1971; Mennucci et al., 1975; Stevens et al., 1976; Inderlied et al., 1980). More recently, we have shown that elevations in the pool levels of polyamines precede all differentiation processes in Mucor rouxii, including the yeast-mycelium transition (Calvo-Mendez et al., 1987; Martinez-Pacheco et al., 1989). These variations were accompanied by changes in ornithine decarboxylase (ODC) activity. ODC is the key enzyme controlling polyamine biosynthesis (Heby, 1981; Tabor \& Tabor, 1984). In $M$. rouxii, inhibition of ODC by the reactionproduct analogue 1,4-diaminobutanone (DAB) blocked spore germination at the transition between the isodiametric and polarized growth stages (Ruiz-Herrera \& Calvo-Mendez, 1987), aerial mycelium formation, and the dimorphic yeast-to-mycelium transition (MartinezPacheco et al., 1989).

In order to investigate whether polyamines play a role in the morphogenesis of C. albicans, we have studied the effect of DAB on the dimorphic transition of this fungus. 


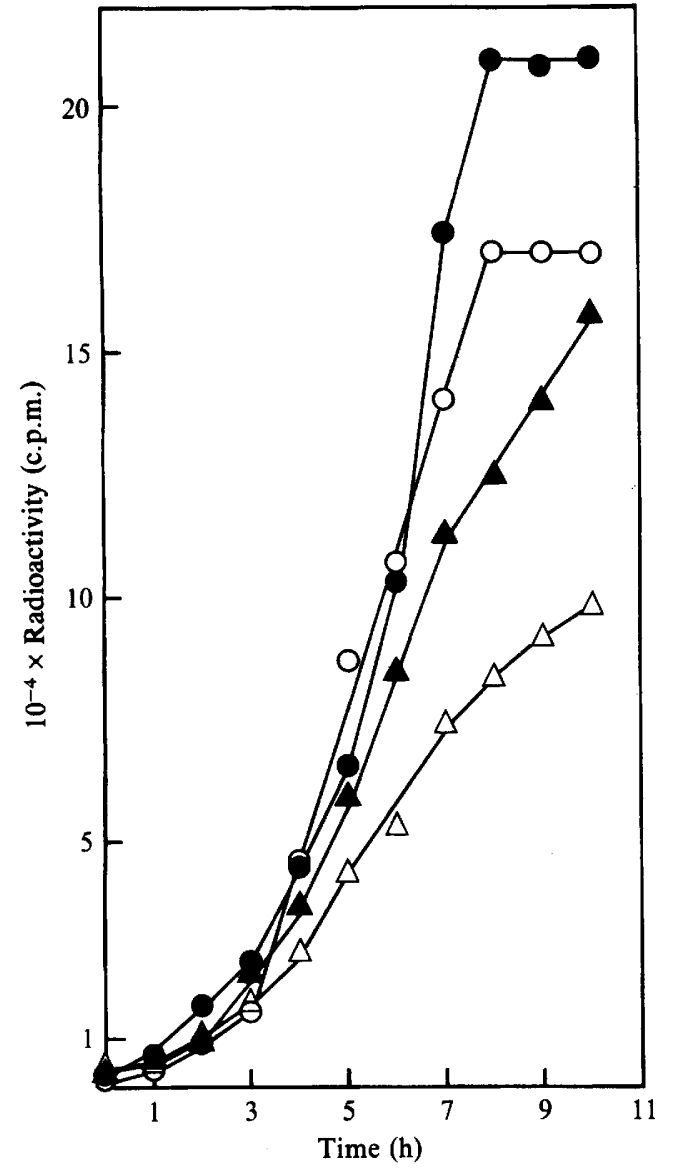

Fig. 1. Effect of DAB on the incorporation of $\left[{ }^{3} \mathrm{H}\right]$ mannose and ${ }^{14} \mathrm{C}$ labelled amino acids into glycoproteins by $C$. albicans. Starved cells grown in synthetic medium containing galactose and peptone, as described in Methods, were inoculated into $25 \mathrm{ml}$ of medium of the same composition containing either $\left[{ }^{3} \mathrm{H}\right]$ mannose $(\mathrm{O}, 0)$ or $\left[{ }^{14} \mathrm{C}\right]$ protein hydrolysate $(\triangle, \Delta)$, in the presence (open symbols) or absence (closed symbols) of $50 \mathrm{mM}-\mathrm{DAB}$, and incubated at $28^{\circ} \mathrm{C}$. At intervals, $1 \mathrm{ml}$ samples were withdrawn, and radioactivity in TCA-insoluble material was measured.

\section{Methods}

Strain and culture conditions. Candida albicans ATCC 26555 was used in this study. It was maintained on slants of Sabouraud dextrose medium (Difco). Unless otherwise indicated, a loopful was inoculated into liquid synthetic medium (Lee $e$ t al., 1975) and incubated with shaking at $28^{\circ} \mathrm{C}$ for $14-16 \mathrm{~h}$. Cells were recovered by centrifugation at $3000 \mathrm{~g}$ for $10 \mathrm{~min}$, washed twice with sterile distilled water, resuspended in sterile distilled water and kept at $4^{\circ} \mathrm{C}$ for $48-96 \mathrm{~h}$ to produce starvation. In some experiments cells were starved in sterile distilled water containing $50 \mathrm{mM}-\mathrm{DAB}$.

Development of yeast or mycelial forms. Starved cells were inoculated into liquid synthetic medium to a final density of $1 \mathrm{mg}$ (dry weight) $\mathrm{ml}^{-1}$ (as calculated from a standard curve relating dry weight to optical density at $600 \mathrm{~nm}$ ), and incubated in a shaking water bath at $28^{\circ} \mathrm{C}$ to obtain the yeast form, or at $37^{\circ} \mathrm{C}$ to develop the mycelial form. The detailed description of the protocol followed to obtain yeast cells and mycelium has been described previously (Casanova et al., 1989).

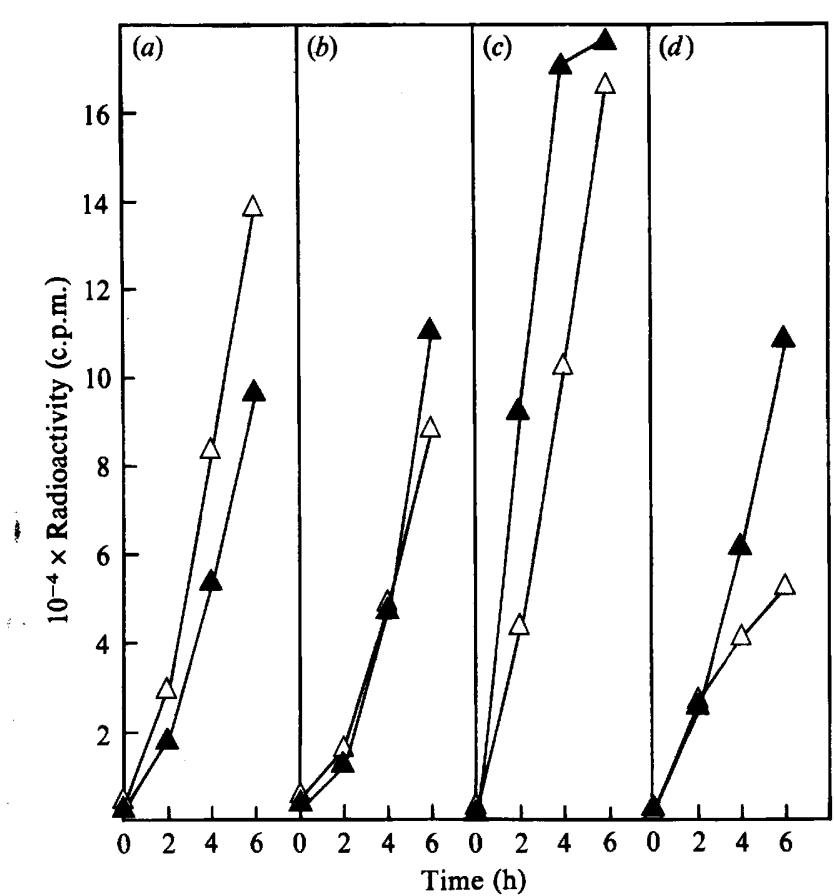

Fig. 2. Effect of pre-growth in the presence of DAB on protein synthesis by $C$. albicans. Cells were pre-grown in the presence $(a, b)$ or absence $(c, d)$ of $50 \mathrm{~mm}-\mathrm{DAB}$, in synthetic medium containing galactose and peptone, and inoculated into $25 \mathrm{ml}$ of media of the same composition supplemented with $\left[{ }^{14} \mathrm{C}\right]$ protein hydrolysate with $(\triangle)$ or without (A) $50 \mathrm{~mm}$-DAB, and incubated at $37^{\circ} \mathrm{C}(a, c)$ or $28^{\circ} \mathrm{C}(b, d)$. At intervals, $1 \mathrm{ml}$ samples were removed, and radioactivity in TCAinsoluble material was measured.

Labelling with radioactive precursors. Cells were grown in the medium described by Lee et al. (1975), except that galactose $\left(12.5 \mathrm{~g} \mathrm{l}^{-1}\right)$ was substituted for glucose, and peptone $\left(20 \mathrm{~g} \mathrm{l}^{-1}\right)$ was added. Cells were grown for 12-14 h, recovered by centrifugation, washed and starved as described above, and inoculated into medium of the same composition supplemented with either $7 \cdot 4 \mathrm{kBq} \mathrm{ml}^{-1}$ of $\left[\mathrm{U}-{ }^{3} \mathrm{H}\right]$ mannose (sp. act. $11.1 \mathrm{GBq} \mathrm{ml}^{-1}$ ) or $11.1 \mathrm{kBq} \mathrm{ml}^{-1}$ of $\left[{ }^{14} \mathrm{C}\right.$ ]protein hydrolysate [sp. act. $2.1 \mathrm{GBq}$ (milligramatom carbon) $\left.{ }^{-1}\right]$. At intervals, samples were recovered, precipitated with an equal volume of $10 \% \mathrm{TCA}$, at $4{ }^{\circ} \mathrm{C}$ for $4 \mathrm{~h}$, filtered through glass fibre filters (Schleicher \& Schuell), washed with TCA and ethanol, and dried. The radioactivity present in the dried filters was measured by liquid scintillation in a Beckman LS-7500 counter. Alternatively, radioactive cultures were used to obtain cell walls.

Cell wall preparation and protein solubilization by digestion with Zymolase. Cell walls from blastoconidia or mycelium were obtained and washed as described by Casanova et al. (1989). Zymolyase treatment $(10 \mu \mathrm{g}$ of enzyme complex per $100-150 \mu \mathrm{g}$ of purified cell walls) and recovery of the released glycoproteins was performed as described by Casanova et al. (1989).

Indirect immunofluorescence for detection of cell surface antigens. This was done as described by Casanova et al. (1989).

SDS-polyacrylamide gel electrophoresis (SDS-PAGE) and blotting. These were performed essentially as described by Martinez et al. (1989) and Casanova et al. (1989). 


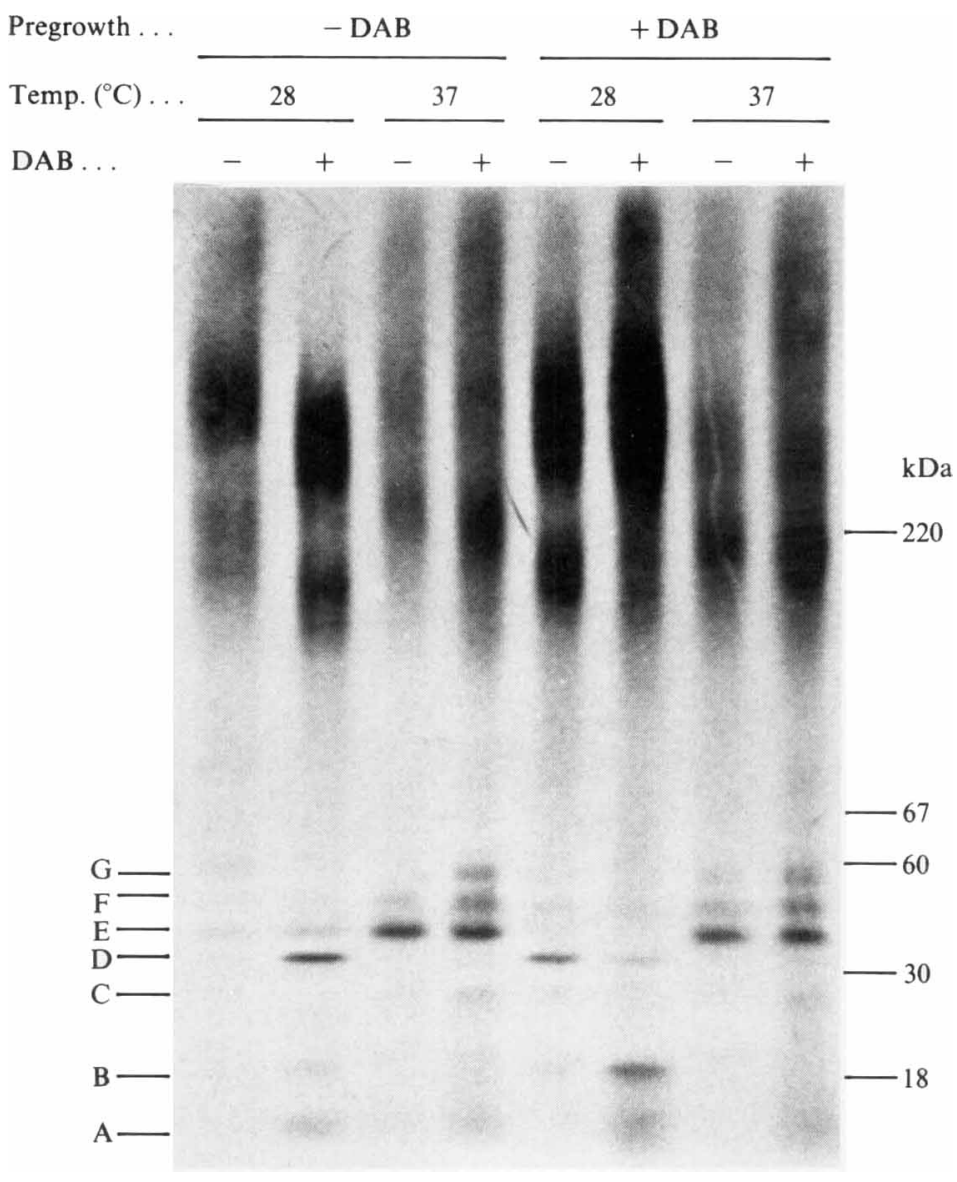

Fig. 3. Radio-labelled proteins liberated from the cell walls of $C$. albicans by Zymolyase treatment. Walls were obtained from cells grown for $6 \mathrm{~h}$ in media containing [ ${ }^{14} \mathrm{C}$ ]protein hydrolysate as described for Fig. 2 . Cell walls were incubated with Zymolyase and the solubilized material was subjected to SDS-PAGE and autoradiography. All lanes contained the same amount of radioactivity (10000 c.p.m.). Positions of molecular mass standards (right), and letter designations of some bands (left, see text), are included.

Miscellaneous. Neutral sugars were measured by the method of Dubois et al. (1956), and protein by the Lowry method. Gel electrophoresis and blotting reagents were from Bio-Rad. SDSmolecular mass markers were from Sigma and Pharmacia. Culture medium compounds were purchased from Difco. Radioactive compounds were obtained from Amersham. Zymolyase 20T was from Miles Laboratories. All other chemicals were from Sigma.

\section{Results and Discussion}

\section{Inhibition of the yeast-mycelial transition by $D A B$}

Incubation of starved cells of C. albicans at $37^{\circ} \mathrm{C}$ resulted in mycelial growth, hyphae reaching maximal length after 5-7 h. After 7-8 h, mycelial cells started to produce new blastospores (see Odds, 1988). Addition of DAB to these cultures did not inhibit mycelial growth, although in the presence of high concentrations (25-50 mM) of the drug, yeast formation in mycelial cultures occurred at shorter time periods, and formation of pseudo-mycelium was noticeable. Thus in 7-h-old control cultures, only about $10 \%$ of the mycelial cells possessed buds, whereas in the presence of $\mathrm{DAB}$, the proportion increased to about $80 \%$. These results were unaffected when DAB was added to $C$. albicans during the starvation period at $4{ }^{\circ} \mathrm{C}$ as well. On the other hand, when the inoculum was grown in the presence of 25-50 mM-DAB, and maintained in its presence during the starvation period and after transfer to fresh medium at $37^{\circ} \mathrm{C}$, the whole population grew in the yeast form. When a DAB-grown inoculum was starved in the presence of $\mathrm{DAB}$, but grown at $37^{\circ} \mathrm{C}$ in the absence of the drug, only partial recovery of mycelial growth was observed. 


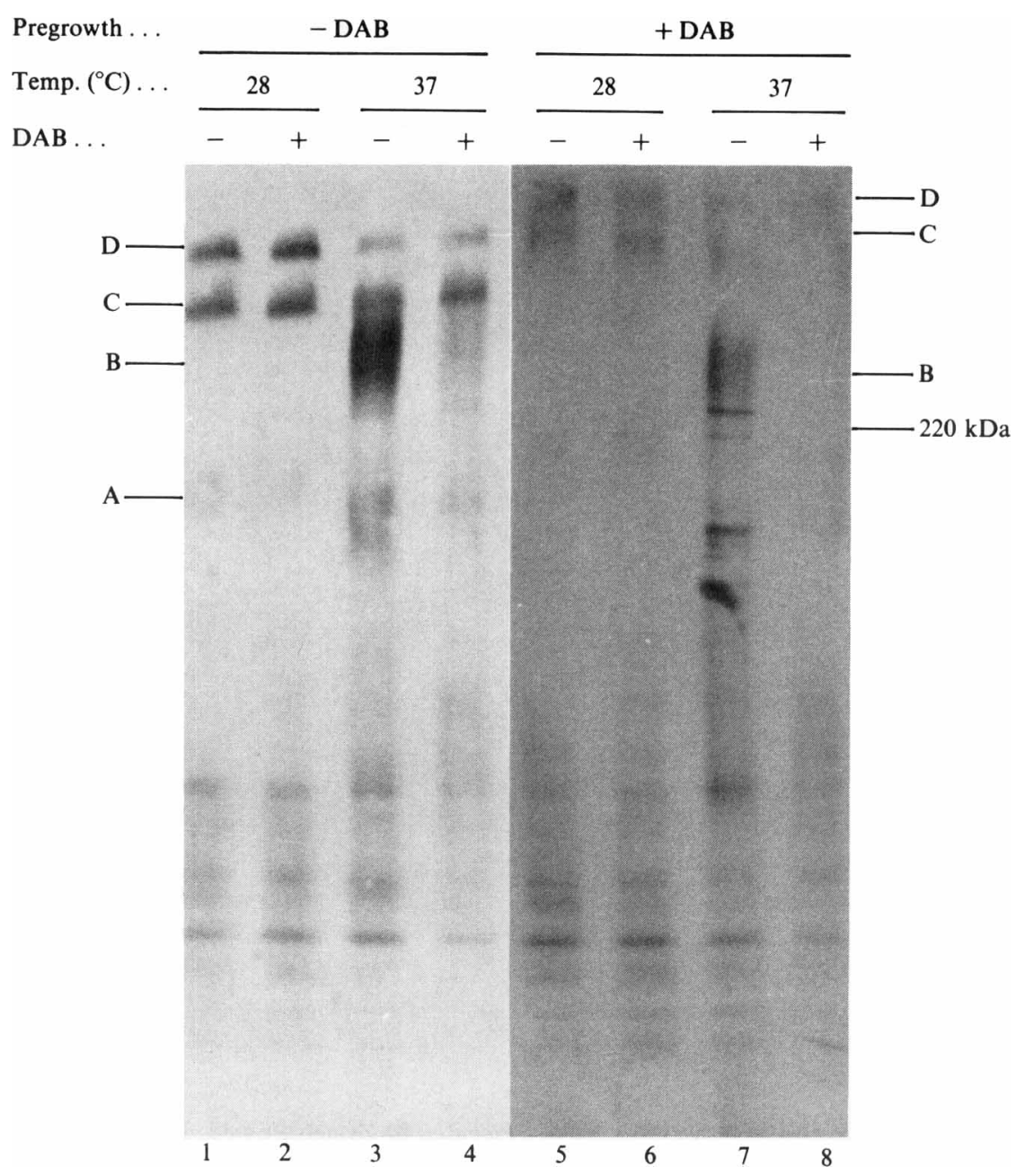

Fig. 4. Electrophoretic pattern of glycoproteins liberated from the cell walls of $C$. albicans by Zymolyase treatment. Walls were obtained from non-radioactive cells, treated with Zymolyase, and the solubilized material was subjected to SDS-PAGE. After blot transfer, proteins were revealed by treatment with Con A. The same amount of neutral carbohydrate was present in all lanes. Misalignment of high-molecular-mass proteins between lanes 1-4 and 5-8 is due to variability in the electrophoretic conditions. The position of a $220 \mathrm{kDa}$ molecular mass standard (right) and designation of some bands by letters (left and right, see text), are included.

These results are evidence that, as in other organisms (Tabor \& Tabor, 1984), polyamines play a key role in differentiation of $C$. albicans. Why it is necessary that DAB be present during the growth of the cells used as inoculum to prevent mycelial transition, in contrast to M. rouxii (Ruiz-Herrera \& Calvo-Mendez, 1987), remains unknown. Preliminary observations suggest that penetration of DAB into the cells occurs by an inducible mechanism. Thus previous exposure of the cells to the drug may be necessary for its uptake.

\section{Effect of DAB on the growth of C. albicans}

At the concentration used (50 mM), DAB did not significantly affect the growth of C. albicans as measured by optical density. Therefore its effect on hyphal formation cannot be ascribed to a general phenomenon of growth inhibition. In further experiments, we measured the incorporation of radiolabelled mannose or amino acids into the cells. Using the protocol described in Methods, it has been previously demonstrated that more than $80 \%$ of the added mannose is incorporated into mannoproteins (M. V. Elorza \& R. Sentandreu, unpublished observations). Fig. 1 shows that $50 \mathrm{~mm}$ DAB inhibited mannose incorporation by about 10 $20 \%$, but only at the late periods of growth of yeast cells, when incorporation reached a plateau, probably because labelled precursors were exhausted. Amino acid incorporation into proteins was inhibited by about $30 \%$ (Fig. 1). Pre-incubation of the cells in the presence of DAB affected their further response to the drug. Synthesis of proteins was slightly stimulated $\left(37^{\circ} \mathrm{C}\right)$ or was not 


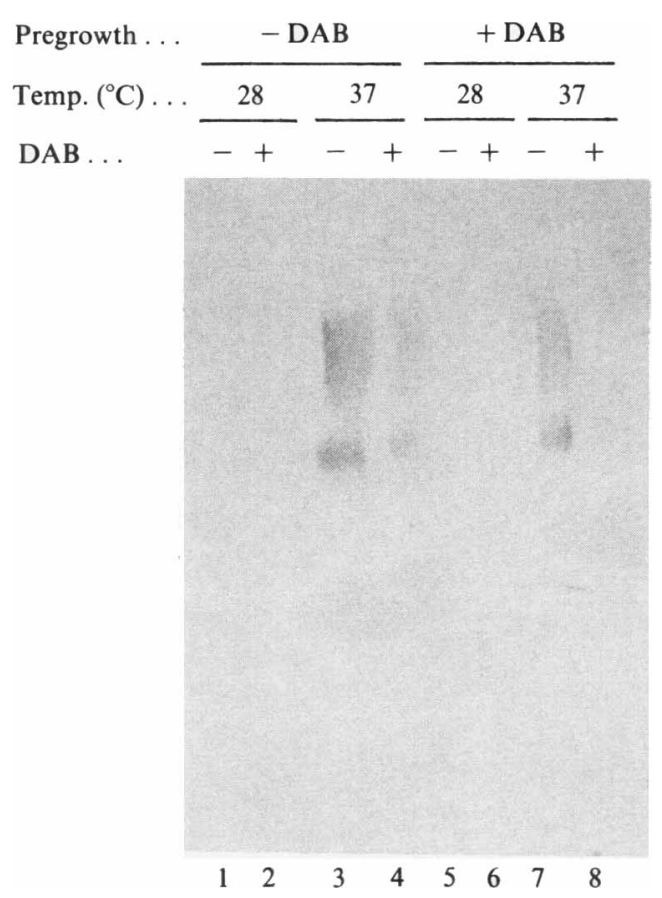

Fig. 5. Effect of DAB on the synthesis of the mycelial wall mannoprotein containing the antigenic determinant recognized by mAb 4C12. The experiment was performed as described for Fig. 4, except that after transfer, the paper sheet was stained with mAb $4 \mathrm{C} 12$.

affected $\left(28^{\circ} \mathrm{C}\right)$ by DAB when cells had previously been grown in the presence of the drug. When cells were pregrown in the absence of DAB, a slight inhibitory effect by the drug was noticed (Fig. 2).

\section{Effect of DAB on the selective synthesis of cell wall mannoproteins in $C$. albicans}

There are important differences in the protein composition of the yeast and hyphal cell walls of $C$. albicans. These differences may be morphogenetically important, and may also affect cell surface properties such as antigenic variation, adhesin expression, cell surface hydrophobicity (Casanova et al., 1989; Douglas, 1987; Elorza et al., 1985; Sundstrom et al., 1987). Accordingly, we analysed the changes induced by DAB in the composition of mannoproteins which are released after digestion of the glucan mesh by Zymolyase treatment. Previous reports from our group indicate that these mannoproteins are the most important in the structural organization of the cell wall (Elorza et al., 1989). This approach is useful in distinguishing those differences directly related to the morphogenetic process from those which are induced by the different temperatures used for yeast or mycelial growth. We observed that of the total radiolabelled protein synthesized, between $0.2 \%$ and
$0.3 \%$ was incorporated into the cell wall, and about 60 $70 \%$ of this was released by Zymolyase treatment, whether cells were pre-grown in DAB or not. These proteins were subjected to SDS-PAGE and autoradiography. Several interesting observations were made regarding the low-molecular-mass proteins synthesized under different conditions (Fig. 3). Several proteins were synthesized at a specific temperature independently of morphology or presence of DAB in either growth period. Proteins $\mathrm{E}$ and $\mathrm{F}$ were synthesized mainly at $37^{\circ} \mathrm{C}$ whereas protein $\mathrm{D}$ was synthesized at $28^{\circ} \mathrm{C}$ only. Proteins A and B increased independently of growth temperature, when DAB was included in the growth medium, whereas levels of proteins $C$ and $G$ were increased at $37^{\circ} \mathrm{C}$ when DAB was included in the growth medium.

Mannoproteins isolated from non-radiolabelled cell walls were analysed by SDS-PAGE, followed by blotting and staining with Concanavalin A (Con A). The results (Fig. 4) show that formation of the very high-molecularmass (>650 kDa) glycoproteins (Fig. 4, bands C and D) was reduced when the cells were pre-grown in the presence of the drug. Note that when unlabelled cell walls are analysed, proteins present in both the yeast inoculum and the yeast or mycelial offspring are visible, whereas the use of radioactive precursor (Fig. 3), labels only the proteins synthesized by the offspring. The two glycoprotein bands specifically associated with the mycelial cell walls (Fig. 4, bands A and B) (Casanova et al., 1989; Elorza et al., 1985) were reduced in intensity when DAB was added during mycelium formation (Fig. 4 , lane 4), and completely absent under the conditions in which DAB inhibits mycelial formation (Fig. 4, lane 8). Removal of DAB during the growth period, a condition which allows partial mycelium formation, gave rise to partial synthesis of the two glycoproteins, although they appeared less polydisperse than in the normal mycelial cells (compare lanes 3 and 7 in Fig. 4).

The latter results were confirmed by use of the monoclonal antibody (mAb 4C12; Casanova et al., 1989) raised against an antigenic determinant present specifically in the polypeptide moiety of high-molecular-mass mannoproteins from the mycelial cell walls (Casanova $e t$ al., 1989; Elorza et al., 1989). Synthesis of the mycelialspecific wall antigen was inhibited under conditions where mycelial formation was blocked by addition of DAB (Fig. 5, lane 8). Absence of DAB during growth of the inoculum, or during further incubation at $37^{\circ} \mathrm{C}$ which did not inhibit (at least not completely) mycelial formation, permitted partial synthesis of the antigen (Fig. 5, lanes 3 and 7).

Inhibition of the synthesis of the mycelial wall-specific antigen was also assessed by direct immunofluorescence analysis of cells grown in the presence of the drug 

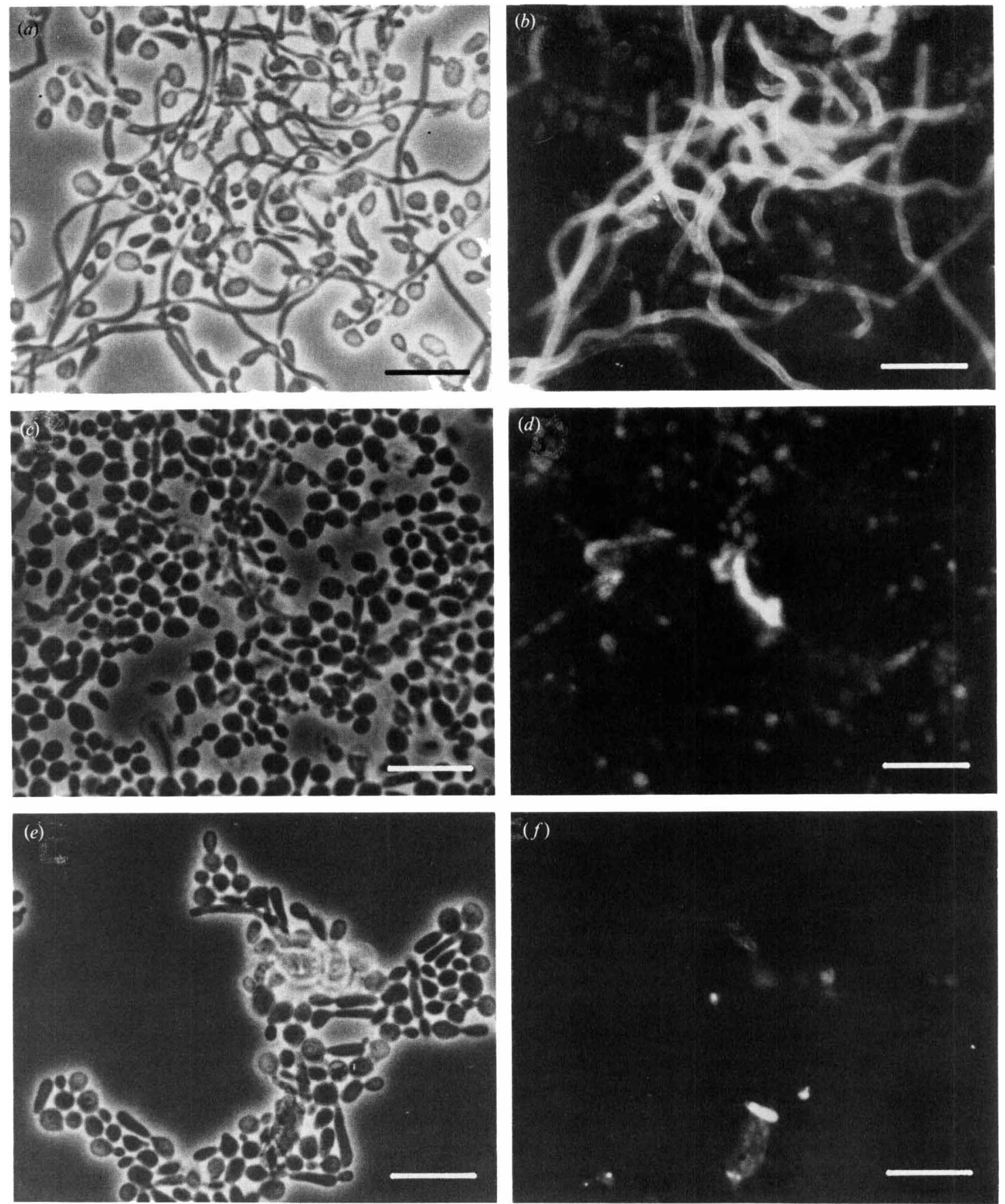

Fig. 6. Fluorescent staining of control and DAB-treated cells with the $\mathrm{mAb} 4 \mathrm{C} 12$. Cells were grown at $37{ }^{\circ} \mathrm{C}$ in either the absence or presence of $50 \mathrm{mM}$-DAB. After $5 \mathrm{~h}$ (control, $a, b)$, and after $3 \mathrm{~h}(c, d)$ or $5 \mathrm{~h}(e, f)$ DAB-treated cells were recovered and stained with the antibody as described in Methods. $(a, c, e)$. Phase contrast; $(b, d, f)$ UV illumination (fluorescence). Fields $(d)$ and $(f)$ show a stained mycelial cell with unstained yeast cells. Bar, $20 \mu \mathrm{m}$.

(Fig. 6d,f) compared to control cells where mycelial formation proceeded normally (Fig. 6 b).

In conclusion, our results establish that DAB inhibits mycelial formation in C. albicans, and switches off the expression of a normal mycelial wall antigen while allowing the expression of normal yeast wall mannoproteins. They also suggest that the high-molecular-mass mannoprotein which contains the mycelial-specific antigen recognized by mAb $4 \mathrm{C} 12$ may play an important role in the morphogenetic process of the fungus. 
This work was partially supported by grants (PB86-172 and PB870606) from the Direccion General de Investigacion Cientifica $y$ Tecnica (Spain), and by CONACyT, DIGICySA of the Secretaria de Educacion Publica and Fundacion Ricardo J. Zevada (Mexico). J.L.L.R. is the recipient of a predoctoral fellowship from the Caja de Ahorros de Valencia (Spain).

\section{References}

ANDERSON, M. L. \& ODDS, F. C. (1985). Adherence of Candida albicans to vaginal epithelia: significance of morphological form and effect of ketoconazole. Mykosen 28, 2035-2047.

Calvo-Mendez, C., Martinez-Pacheco, M. \& Ruiz-Herrera, J. (1987). Regulation of ornithine decarboxylase activity in Mucor bacilliformis and Mucor rouxii. Experimental Mycology 11, 270-277.

Casanova, M., Gil, M. L., Cardenoso, L., Martinez, J. P. \& SENTANDREU, R. (1989). Identification of wall-specific antigens synthesized during germ tube formation by Candida albicans. Infection and Immunity 57, 262-271.

Cawson, R. A. \& RajasinghaM, K. C. (1972). Ultrastructural features of the invasive phase of Candida albicans. Journal of Dermatology 87 , 435-443.

Douglas, L. J. (1987). Adhesion of Candida species to epithelial surfaces. CRC Critical Reviews in Microbiology 15, 27-43.

Dubois, M., Gilles, K. A., Hamilton, J. K., Rebers, P. A. \& Smith, F. (1956). Colorimetric method for determination of sugars and related substances. Analytical Chemistry 28, 350-356.

Elorza, M. V., Murgui, A. \& Sentandreu, R. (1985). Dimorphism in Candida albicans: contribution of mannoproteins to the architecture of yeast and mycelial cell walls. Journal of General Microbiology 131, 2209-2216.

Elorza, M. V., Mormeneo, S., Garcia de la Cruz, F., Gimeno, C. \& SENTANDREU, R. (1989). Evidence for the formation of covalent bonds between macromolecules in the domain of the wall of Candida albicans mycelial cells. Biochemical and Biophysical Research Communications 162, 1118-1125.

FarRel, S. M., Hawkins, D. F. \& Ryder, T. A. (1983). Scanning electron microscope study of Candida albicans invasion of cultured human cervical epithelial cells. Sabouraudia 21, 251-254.

HEBY, O. (1981). Role of polyamines in the control of cell proliferation and differentiation. Differentiation 14, 1-20.

INDERLIED, C. B., CiHLAR, R. L. \& SYPHERD, P. S. (1980). Regulation of ornithine decarboxylase during morphogenesis of Mucor racemosus. Journal of Bacteriology 141, 699-706.
KIM, W. K. (1971). Folate and polyamine content of indifferentiated and differentiated wheat stem rust uredosporelings. Canadian Journal of Botany 49, 1119-1122.

Kimura, L. H. \& Pearsall, N. N. (1980). Relationship between germination of Candida albicans and increased adherence to human buccal epithelial cells. Infection and Immunity 28, 464-468.

LeE, K. L., BuCKLeY, H. R. \& CAMPBell, C. (1975). An amino acid liquid synthetic medium for development of mycelial and yeast forms of Candida albicans. Sabouraudia 13, 148-153.

Martinez, J. P., Gil, M. L., Casanova, M., Rico, H., Sentandreu, R. \& RUIZ-HERRERA, J. (1989). Characterization of a proteinaceous extracellular coat synthesized by the 'slime' variant of Neurospora crassa. Archives of Microbiology 152, 25-32.

Martinez-Pacheco, M., Rodriguez, G., Reyna, G., CalvoMendeZ, C. \& RUIZ-HerRerA, J. (1989). Inhibition of the yeastmycelial transition and the phorogenesis of Mucorales by diaminobutanone. Archives of Microbiology 151, 10-14.

Mennucci, L., Rojas, S. \& Camargo, E. P. (1975). Polyamines and ornithine decarboxylase activity during growth and differentiation in Blastocladiella emersonii. Biochimica et Biophysica Acta 404, 249256.

ODDS, F. C. (1988). Candida and Candidosis, 2nd edn. London: Baillière Tindall.

Rajasingham, K. C. \& Cawson, R. A. (1982). Ultrastructural identification of extracellular material and appresoria in Candida albicans. Cytobios 35, 77-83.

Ruiz-Herrera. J. \& Calvo-Mendez, C. (1987). Effect of ornithine decarboxylase inhibitors on the germination of sporangiospores of Mucorales. Experimental Mycology 11, 287-296.

SANDIN, R. L. \& ROGERS, A. L. (1982). Inhibition of adherence of Candida albicans to human epithelial cells. Mycopathologia 77, 23-36.

SMITH, C. B. (1985). Candidiasis: pathogenesis, host resistance and predisposing factors. In Candidiasis, pp. 53-70. Edited by G. P. Bodey \& V. Fainstein. New York: Raven Press.

SOBEL, J. D. \& OBEDEANU, N. (1983). Effects of subinhibitory concentrations of ketoconazole on in vitro adherence of Candida albicans to vaginal epithelial cells. European Journal of Clinical Microbiology 2, 445-452.

Soll, D. R. (1985). Candida albicans. In Fungal Dimorphism: with Emphasis on Fungi Pathogenic to Humans, pp. 167-195. Edited by P. J. Szanislo. New York: Plenum Publishing Co.

Stevens, L., McKinnon, I. M. \& Winther, M. D. (1976). Polyamine metabolism during the germination of conidia of Aspergillus nidulans. Biochemical Journal 158, 235-241.

Sundstrom, P. M., Nichols, E. J. \& KeNNY, G. E. (1987). Antigenic differences between mannoproteins of germ tubes and blastospores of Candida albicans. Infection and Immunity 55, 616-620.

TABOR, C. W. \& TABOR, H. (1984). Polyamines. Annual Review of Biochemistry 53, 749-790. 